\title{
Pitfalls and solutions of the fully-automated radiosynthesis of $\left[{ }^{11} \mathrm{C}\right]$ metoclopramide
}

\author{
Verena Pichler ${ }^{1 *}$ (D), Marius Ozenil ${ }^{1}$, Karsten Bamminger ${ }^{1,2}$, Chrysoula Vraka ${ }^{1}$, Marcus Hacker ${ }^{1}$, Oliver Langer ${ }^{1,3,4}$ \\ and Wolfgang Wadsak ${ }^{1,2}$
}

\author{
*Correspondence: verena.pichler@ \\ meduniwien.ac.at \\ ${ }^{1}$ Division of Nuclear Medicine, \\ Department of Biomedical Imaging \\ and Image-guided Therapy, Medical \\ University of Vienna, Vienna, Austria \\ Full list of author information is \\ available at the end of the article
}

\begin{abstract}
Background: $\left[{ }^{11} \mathrm{C}\right]$ Metoclopramide is a new radiotracer for investigating the activity of P-glycoprotein at the blood-brain barrier. A highly stable and reproducible radiosynthesis is a prerequisite for clinical studies applying $\left[{ }^{11} \mathrm{C}\right]$ metoclopramide or other ${ }^{11} \mathrm{C}$-labelled radiotracers, therefore all potential pitfalls must be identified and monitored to allow a stable process.

Results: Long-term production ( $n=94$ in a time range of approximately 2 years) of $\left[{ }^{11} \mathrm{C}\right]$ metoclopramide synthesized on two commercially available synthesizers yielded $3.9 \pm 2.0 \mathrm{GBq}$ of product with a molar activity of $132 \pm 164 \mathrm{GBq} / \mu \mathrm{mol}$ and an overall success rate of $93 \%$. During all successful productions, the product quality was in accordance with the recommendations of the European Pharmacopoeia. The most common pitfalls that were identified for the radiosynthesis included poor turnover into $\left[{ }^{11} \mathrm{C}\right] \mathrm{CH}_{3} \mathrm{OTf}$, decomposition of the solvent or insufficient semi-preparative HPLC performance.
\end{abstract}

Conclusion: The study provides long-term insight in the improved, robust and stable preparation of $\left[{ }^{11} \mathrm{C}\right]$ metoclopramide for human use.

Keywords: $\left[{ }^{11} \mathrm{C}\right]$ metoclopramide, carbon-11, radiosynthesis, blood-brain-barrier, PET

\section{Background}

$\left[{ }^{11} \mathrm{C}\right]$ Metoclopramide is a novel positron emission tomography (PET) radiotracer, which has been developed to measure the activity of P-glycoprotein (P-gp) at the blood-brain-barrier, an important efflux transporter, which restricts the brain distribution of many different drugs (Bauer et al. 2019; Tournier et al. 2019; Auvity et al. 2018; Pottier et al. 2016). $\left[{ }^{11} \mathrm{C}\right]$ Metoclopramide is a weak P-gp substrate, which has considerably higher brain uptake under conditions of full P-gp function as compared with previously described avid P-gp substrates for PET (e.g. $\left[{ }^{11} \mathrm{C}\right]$ verapamil or $\left[{ }^{11} \mathrm{C}\right] \mathrm{N}$ desmethyl-loperamide). Consequently, $\left[{ }^{11} \mathrm{C}\right]$ metoclopramide may possess a better sensitivity to measure moderate changes in P-gp function at the blood-brain barrier than previously described radiotracers (Bauer et al. 2019). Carbon-11 is an attractive radionuclide for PET imaging as it allows to radiolabel most drug molecules without structural changes. Moreover, its short radioactive half-life $(20.4 \mathrm{~min})$ leads to relatively low radiation exposure of study participants and allows for repeated PET scanning within one imaging session (e.g. two consecutive scans without and with pre-treatment with a

(c) The Author(s). 2019 Open Access This article is distributed under the terms of the Creative Commons Attribution 4.0 International License (http://creativecommons.org/licenses/by/4.0/), which permits unrestricted use, distribution, and reproduction in any medium, provided you give appropriate credit to the original author(s) and the source, provide a link to the Creative Commons license, and indicate if changes were made. 
P-gp inhibitor). For a successful clinical application, stable and reliable radiosynthesis procedures are therefore a prerequisite.

Here, we present the fully-automated radiosynthesis of $\left[{ }^{11} \mathrm{C}\right]$ metoclopramide (Fig. 1) conducted with a GE TRACERlab $^{\text {tw }}$ FX C Pro or GE TRACERlab ${ }^{\text {tw }}$ FX2 C system, respectively. The main pitfalls of the radiosynthesis were identified e.g. decomposition of solvent or insufficient separation on semi-preparative HPLC and appropriate solutions were implemented.

\section{Material and methods}

All chemicals were obtained from commercial sources and used as received. The precursor $\mathrm{O}$-desmethyl-metoclopramide (GMP grade) as well as the reference compound metoclopramide (4-amino-5-chloro- $N$-[2-(diethylamino)ethyl]-2-methoxy-benzamide) were purchased from ABX (Radeberg, Germany). The Ni catalyst (Shimalilte Ni reduced, 80/100 mesh) was purchased from Shimadzu (Kyoto, Japan). SepPak ${ }^{\circ}$ C18 plus cartridges for solid-phase extraction were purchased from Waters (Waters ${ }^{\bullet}$ Associates Milford, MA, USA). Low-protein binding Millex GS $0.22 \mu \mathrm{m}$ sterile filters were purchased from Millipore ${ }^{\circ}$ (Bedford, MA, USA). The silver triflate column was prepared according to the recommendation of the module producer General Electric Medical System, Uppsala, Sweden. Silver triflate and carbopack adsorbent C, 80-100 mesh was obtained by Sigma Aldrich and used as received.

\section{Instrumentation}

$\left[{ }^{11} \mathrm{C}\right] \mathrm{CO}_{2}$ was produced in a GE PETtrace 860 cyclotron (General Electric Medical System, Uppsala, Sweden) via the ${ }^{14} \mathrm{~N}(\mathrm{p}, \alpha){ }^{11} \mathrm{C}$ nuclear reaction by irradiation of a gas target (aluminium) filled with $\mathrm{N}_{2}+1 \% \mathrm{O}_{2}$ (Air Liquide, Vienna, Austria). Typical beam currents were $60-65 \mu \mathrm{A}$ and the irradiation was stopped as soon as the desired activity level was reached (approx. $80-130 \mathrm{GBq}\left[{ }^{11} \mathrm{C}\right] \mathrm{CO}_{2}$; corresponding to $30-40 \mathrm{~min}$ irradiation time). The synthesis of $\left[{ }^{11} \mathrm{C}\right]$ metoclopramide starting from $\left[{ }^{11} \mathrm{C}\right] \mathrm{CO}_{2}$ (Fig. 1) was performed in two different GE modules (GE Healthcare, Uppsala, Sweden), namely a TRACERlab $^{\text {tw }}$ FX C Pro and a TRACERlab ${ }^{\text {Tx }}$ FX2 C module. For analytical HPLC, an Agilent 1260 system was used, which was equipped with a quaternary pump (G1311B), a multi wavelength UV-detector (G1365D), a column oven (G1316A), a manual injector (G1328C), as well as a radio-detector controlled by GINA Star software (Elysia-Raytest; Straubenhardt, Germany). Osmolality of the formulated radiotracer solution was

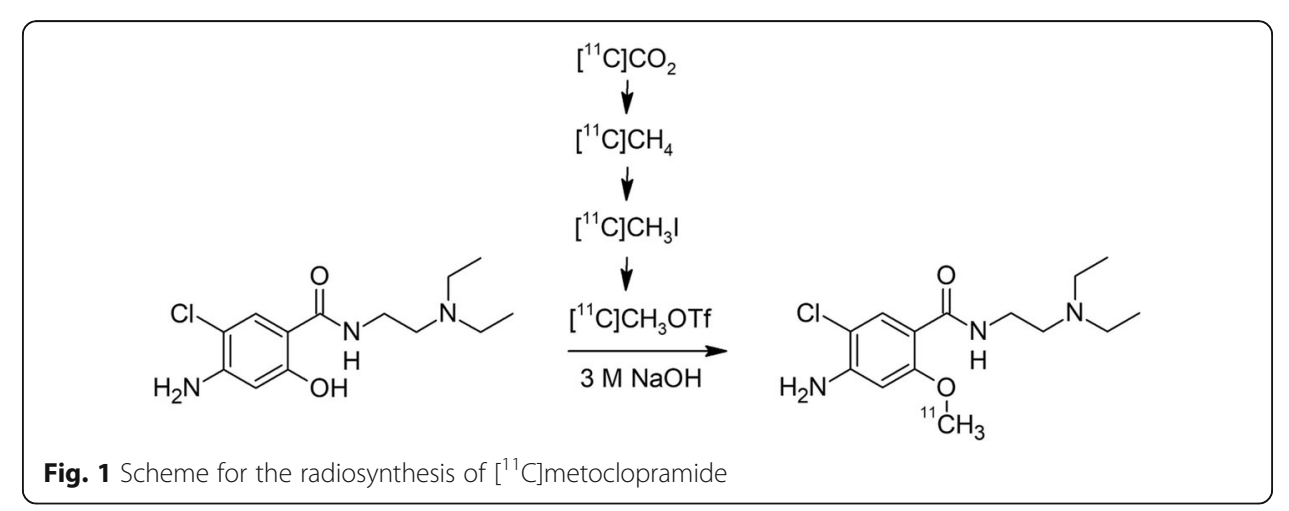


measured using a Wescor osmometer Vapro 5600 (Sanova Medical Systems, Vienna, Austria) and $\mathrm{pH}$ was always measured using a WTW inoLab $740 \mathrm{pH}$ meter (WTW, Weilheim, Germany) for every released product. Gas chromatography was performed using a 430-GC system (Bruker Daltonik GmbH, Bremen, Germany) and a capillary column (forte GC Capillary Column ID-BP20; $12 \mathrm{~m} \times 0.22 \mathrm{~mm} \times 0.25 \mu \mathrm{m}$ ) from SGE Analytical Sciences Pty Ltd. (Victoria, Australia). Butanone was analysed with a Bruker Avance III 200 spectrometer $\left(200 \mathrm{MHz}\right.$ for $\left.{ }^{1} \mathrm{H}\right)$.

\section{Preparation of the synthesizers}

The flow charts of the TRACERlab ${ }^{\text {tw }}$ FX C Pro and FX2 C are depicted in Fig. 2. All parts involved in the radiosynthesis were first flushed with helium and subsequently checked for tightness by applying a helium flow of $100 \mathrm{~mL} / \mathrm{min}$, which has to decrease below $4 \mathrm{~mL} / \mathrm{min}$ when all lines are tightly sealed. The methyl iodide trap was heated to $200{ }^{\circ} \mathrm{C}$ for approximately $20 \mathrm{~min}$ and afterwards cooled down to $\leq 35^{\circ} \mathrm{C}$. The silver triflate column was preheated to $200^{\circ} \mathrm{C}$ before start of the synthesis for approximately 15 min. The reaction vessels V1-V3 and the corresponding transfer lines via the reaction vial and HPLC injection loop into the waste were washed twice with water and acetone. Complete removal of all traces of solvent was assured by visual inspection of all connected tubes. The radiotracer formulation part of the module was washed with water and ethanol including the bulb and product collection vial. The preparation procedure was performed similarly for the GE TRACERlab ${ }^{\text {TM }}$ FX C Pro and TRACERlab $^{\text {ti }}$ FX2 C. A detailed protocol for the module preparation was published recently (Vraka et al. 2019).

The reaction vials were filled with $1 \mathrm{~mL}$ water (aqua ad injectabilia; V2), $5 \mathrm{~mL}$ sodium chloride 9\% (V4), $1.5 \mathrm{~mL}$ ethanol (V5) and $10 \mathrm{~mL}$ water (aqua ad injectabilia; V6). The bulb was filled with $80 \mathrm{~mL}$ of water (aqua ad injectabilia), a C18 Plus Sep-Pak (equilibrated with $10 \mathrm{~mL}$ ethanol and $20 \mathrm{~mL}$ water) was placed on the Sep-Pak position and 6 $\mathrm{mL}$ of phosphate buffered saline (prepared by Vienna General Hospital pharmacy, Austria; $0.021 \mathrm{M}$ phosphate buffer, $0.188 \mathrm{M} \mathrm{NaCl}, \mathrm{pH}$ 7.7) were placed in the product collection vial. For patient application, a product vial with sterile filter and sterile air ventilation was prepared in a laminar air flow cell and connected to the product tubing. Prior to use, the reaction vessel had been stored at $100^{\circ} \mathrm{C}$ for at least $4 \mathrm{~h}$. Immediately before start of the radiosynthesis, $1 \mathrm{mg}$ of $\mathrm{O}$-desmethyl-metoclopramide $(3.5 \mu \mathrm{mol})$ was dissolved in $400 \mu \mathrm{L}$ butanone and transferred to the reaction vessel. Then $7 \mu \mathrm{L}$ of $3 \mathrm{M}$ aqueous $\mathrm{NaOH}$ solution $(21 \mu \mathrm{mol}, 6$ equivalents) was added to deprotonate the phenol.

\section{Fully-automated radiosynthesis of $\left[{ }^{11} \mathrm{C}\right]$ metoclopramide}

The synthesis sequence started with a 15-20 min pre-run including heating of the carbon dioxide trap to $400{ }^{\circ} \mathrm{C}$ and subsequent cooling to $<50^{\circ} \mathrm{C}$. During the heating process, the trap was continuously flushed with helium $(50 \mathrm{~mL} / \mathrm{min})$. When $400^{\circ} \mathrm{C}$ was reached, $3 \mathrm{~min}$ of hydrogen pre-equilibration of the carbon dioxide trap took place. Afterwards the carbon dioxide trap was cooled to $<50{ }^{\circ} \mathrm{C}$ and the methane trap was cooled to $-75^{\circ} \mathrm{C}$ ending the pre-run with the comment 'ready to receive activity'.

The automatic radiosynthesis was then started by delivering $116 \pm 17 \mathrm{GBq}$ of $\left[{ }^{11} \mathrm{C}\right] \mathrm{CO}_{2}$ to the carbon dioxide trap and confirmation of the end of delivery. The gas 


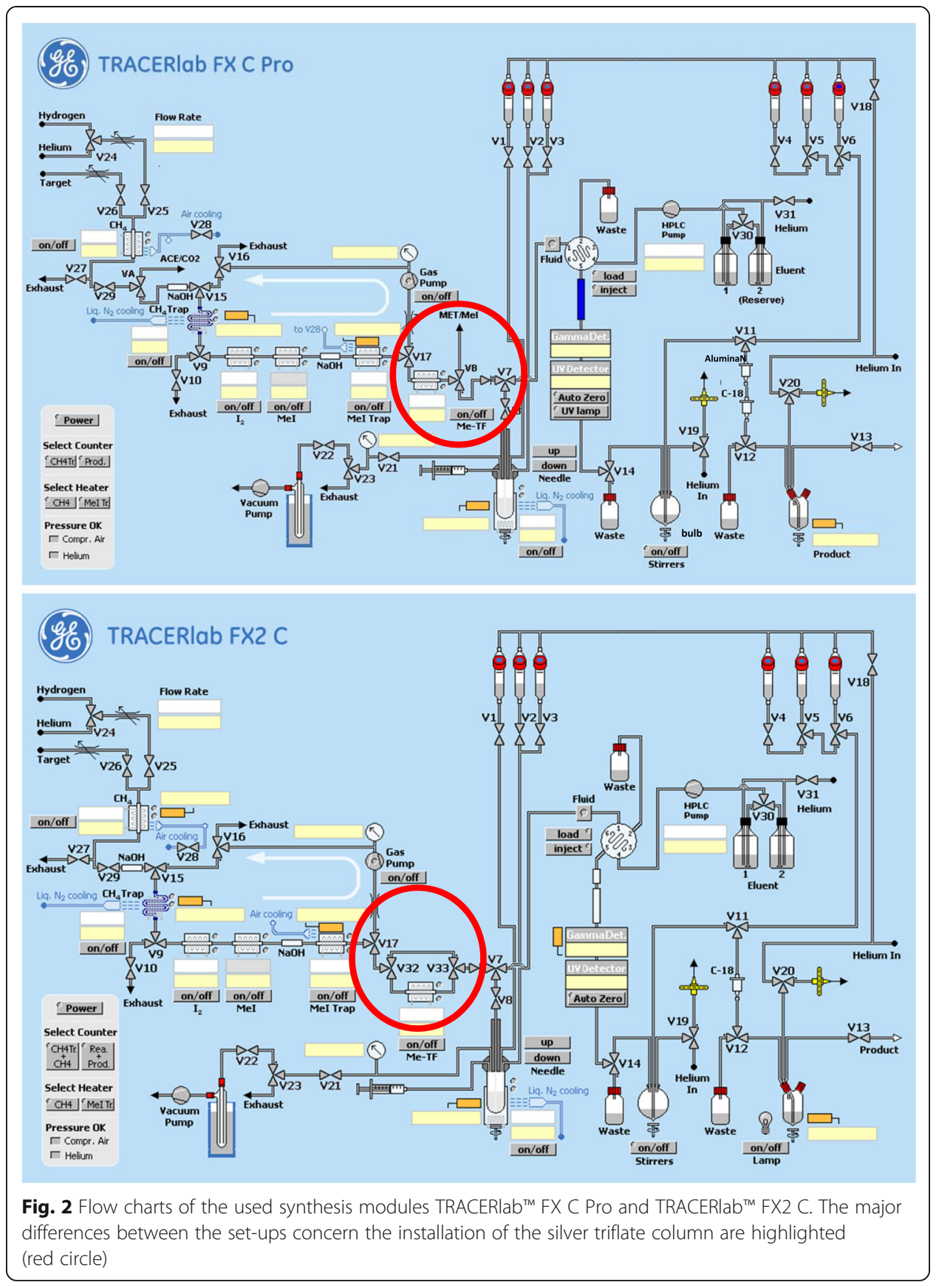

phase transformation of $\left[{ }^{11} \mathrm{C}\right] \mathrm{CO}_{2}$ via the formation of $\left[{ }^{11} \mathrm{C}_{\mathrm{CH}_{4}}\right.$ produced approximately $50 \mathrm{GBq}$ of $\left[{ }^{11} \mathrm{C}\right] \mathrm{CH}_{3} \mathrm{I}$ and has been described in detail elsewhere (Vraka et al. 2019; Pichler et al. 2018a; Philippe et al. 2018; Larsen et al. 1997). $\left[{ }^{11} \mathrm{C}^{-} \mathrm{CH}_{3} \mathrm{OTf}\right.$ was produced by passing $\left[{ }^{11} \mathrm{C}\right] \mathrm{CH}_{3} \mathrm{I}$ gas through the silver triflate column at $200^{\circ} \mathrm{C}$. After completion of the activity trapping within the reaction mixture, the reaction took place at $110^{\circ} \mathrm{C}$ for $2 \mathrm{~min}$. Afterwards the reaction mixture was quenched with water from V2 and transferred to the semi-preparative HPLC via the injection valve. For semipreparative HPLC, a SUPELCOSIL LC-ABZ+ column $(5 \mu \mathrm{m}, 250 \mathrm{~mm} \times 10 \mathrm{~mm})$ from Merck (Darmstadt, Germany) was eluted with freshly prepared $20 \mathrm{mM}$ aqueous 
$\mathrm{NaH}_{2} \mathrm{PO}_{4} /$ acetonitrile $(80 / 20)$ at a flow rate of $5 \mathrm{~mL} / \mathrm{min}$ with $\mathrm{UV}$ absorption measured at $254 \mathrm{~nm}$ (Fig. 3).

In total, 70 syntheses were performed on the TRACERlab ${ }^{\text {tw }}$ FX C Pro, of which the first eight syntheses were performed for establishment and evaluation of the automated radiosynthesis and analytical and preparative HPLC establishment. These syntheses were excluded from statistical analysis as the final activity yield was not always measured. Three syntheses failed, caused by insufficient transfer of the activity into the reactor (no formation of $\left[{ }^{11} \mathrm{C}\right] \mathrm{CH}_{3} \mathrm{I}$ or $\left[{ }^{11} \mathrm{C}\right] \mathrm{CH}_{3} \mathrm{OTf}$ ), insufficient separation or no product formation at all besides other technical issues. Thirty-eight radiosyntheses were performed so far on the GE TRACERlab ${ }^{\text {tw }}$ FX2 C, of which six syntheses were performed for validation of the new module (excluded data) and four synthesis failed. Out of these productions ( $n=94$, excluding test syntheses, 7 fail synthesis), 81 radiosynthesis were released for clinical application, the remaining six productions were released but for other applications. Details on optimization radiosyntheses performed, which were not released for human application but are included in the overall analysis are shown in Table 1. The success rate of $\left[{ }^{11} \mathrm{C}\right]$ metoclopramide produced on TRACERlab ${ }^{\text {tw }}$ FX C Pro or GE TRACERlab ${ }^{\text {tw }}$ FX2 C was 95 and $88 \%$, respectively. The productions were performed between August 2017 and September 2019. The change of the synthesis module was implemented in December 2018.

\section{Quality control of $\left[{ }^{11} \mathrm{C}\right]$ metoclopramide}

The quality control parameters encompassed the parameters $\mathrm{pH}$, osmolality, organic solvent content, radionuclidic purity, radiochemical and chemical purity as well as biological testing of sterility and endotoxins. All tests performed were in accordance with the recommendations of the European Pharmacopoeia for other ${ }^{11} \mathrm{C}$-radiotracers. The chemical and radiochemical purity was measured by means of RP-HPLC using an XBridge BEH Shield RP-18, $4.6 \times 50$ mm, $2.5 \mu \mathrm{m}, 130 \AA$ (Waters GmbH) column eluted at a flow rate of $1 \mathrm{~mL} / \mathrm{min}$ with a gradient program (Fig. 4) of the following solvents:

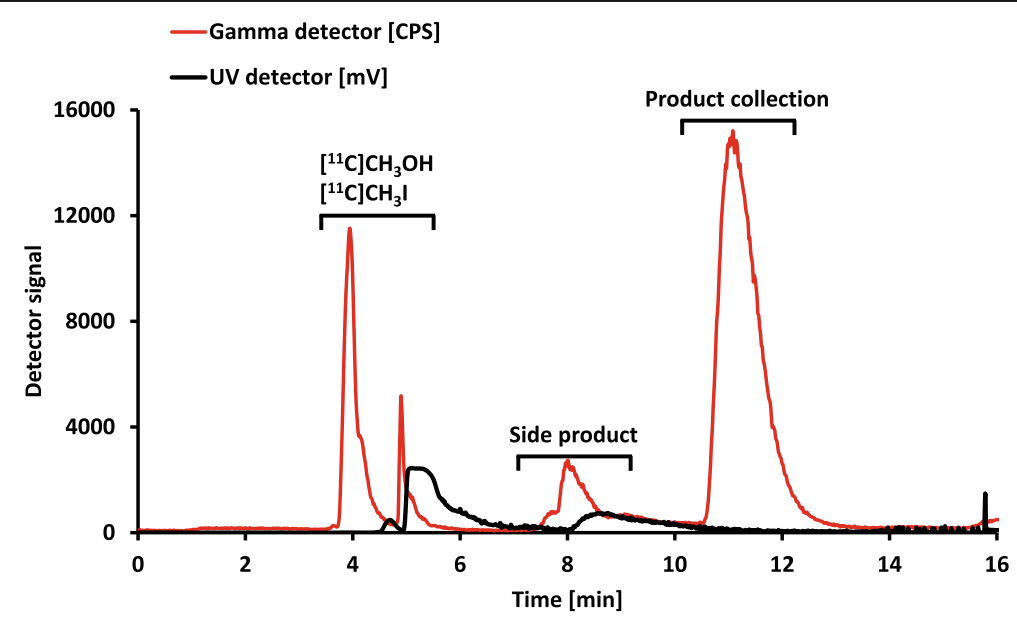

Fig. 3 Typical semi-preparative RP-HPLC chromatogram of a $\left[{ }^{11} \mathrm{C}\right]$ metoclopramide radiosynthesis including the signal of the UV-detector $(254 \mathrm{~nm}$, black) and radio-detector (red). The product peak has a retention time of approximately $10.5-12.5 \mathrm{~min}$ 
Table 1 Overview on evaluation batches and overall yield of $\left[{ }^{11} \mathrm{C}\right]$ metoclopramide productions with changing reaction conditions

\begin{tabular}{|c|c|c|c|}
\hline Solvent & $\begin{array}{l}\text { Reactive } \\
\text { synthon }\end{array}$ & $\begin{array}{l}\mathrm{RCY}\left(\% \text { based on }\left[{ }^{11} \mathrm{C}\right] \mathrm{CO}_{2} \text {, decay }\right. \\
\text { corrected) }\end{array}$ & $\begin{array}{l}\text { Activity yield } \\
\text { [GBq] }\end{array}$ \\
\hline Acetone $(n=3)$ & {$\left[{ }^{11} \mathrm{C}\right] \mathrm{CH}_{3} \mathrm{OTf}$} & $20.7 \pm 4.5 \%$ & $5.4 \pm 1.2$ \\
\hline $\begin{array}{l}\text { Butanone ( } n=3 \text {, evaluation } \\
\text { batches) }\end{array}$ & {$\left[{ }^{11} \mathrm{C}\right] \mathrm{CH}_{3} \mathrm{OTf}$} & $20.8 \pm 3.8 \%$ & $6.3 \pm 1.7$ \\
\hline Butanone $(n=1)$ & {$\left[{ }^{11} \mathrm{C}\right] \mathrm{CH}_{3} \mathrm{l}$} & no product & 0 \\
\hline $\begin{array}{l}\text { Butanone ( } n=94 \text {, overall } \\
\text { productions) }\end{array}$ & {$\left[{ }^{11} \mathrm{C}\right] \mathrm{CH}_{3} \mathrm{OTf}$} & $13.2 \pm 6.7$ & $3.9 \pm 2.0$ \\
\hline
\end{tabular}

solvent A: aqueous acetonitrile (90\%), solvent B: water and solvent C: aqueous ammonium phosphate buffer $(50 \mathrm{mM})$, pH 9.3 adjusted with $\mathrm{NaOH}$ (Nics et al. 2018). The retention time of the precursor $O$-desmethyl-metoclopramide was between $1 \mathrm{~min} 20 \mathrm{~s}$ to $1 \mathrm{~min} 50 \mathrm{~s}$ and for the product $\left[{ }^{11} \mathrm{C}\right]$ metoclopramide $2 \mathrm{~min} 50 \mathrm{~s}$ to $3 \mathrm{~min} 20 \mathrm{~s}$ (Fig. 5). The calibration curve was set up at $225 \mathrm{~nm}$ for the concentration range $0.1-5 \mu \mathrm{g} / \mathrm{mL}$ $(0.1,0.5,2,3.5$ and $5 \mu \mathrm{g} / \mathrm{mL}$ standards) including blank measurements all performed in at least three repetitions (Fig. 4).

The retention times were checked prior every radiosynthesis by injection of the respective reference compounds. Both, the semi-preparative as well as the analytical HPLC systems were tested for the retention times of the reactive intermediates methyl iodide, methyl triflate and methanol (from the reaction of methyl triflate with water) as well as $\left[{ }^{11} \mathrm{C}\right] \mathrm{CH}_{3} \mathrm{I},\left[{ }^{11} \mathrm{C}\right] \mathrm{CH}_{3} \mathrm{OTf},\left[{ }^{11} \mathrm{C}\right] \mathrm{CO}_{2}$ and a mixture of $\left[{ }^{11} \mathrm{C} \mathrm{CH}_{3} \mathrm{OTf}\right.$ with water (for the retention time of $\left[{ }^{11} \mathrm{C}\right] \mathrm{CH}_{3} \mathrm{OH}$ ).

\section{Statistical analysis}

Yield calculation consisted of the measured activity of the product in GBq corrected for decay divided by the produced starting activity of $\left[{ }^{11} \mathrm{C}\right] \mathrm{CO}_{2}$ in $\mathrm{GBq}$ and is expressed in $\%$ if not stated otherwise (Coenen et al. 2017).

A

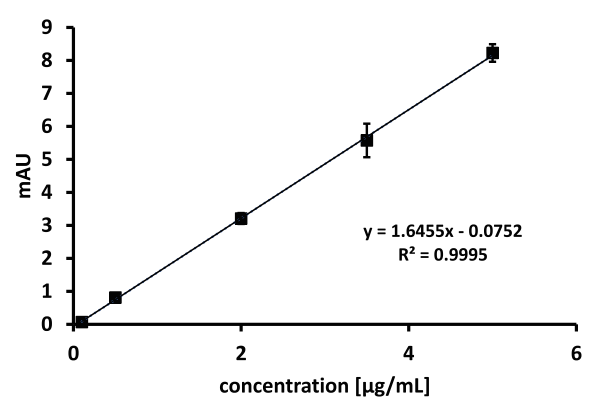

B

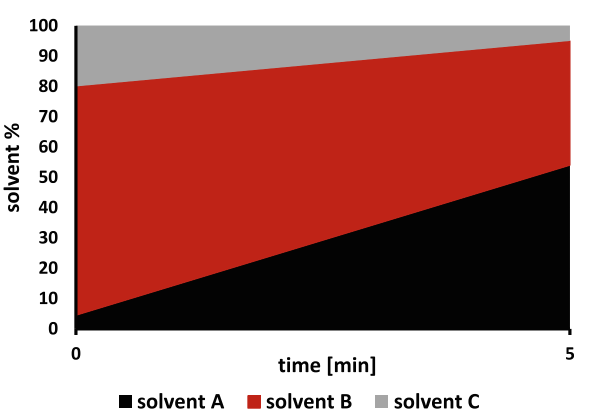

Fig. 4 a Calibration curve of metoclopramide in the range of $0.1-5 \mu \mathrm{g} / \mathrm{mL}$ measured at a wavelength of $225 \mathrm{~nm}$. The limit of detection and limit of quantification were $0.2 \mu \mathrm{g} / \mathrm{mL}$ and $0.7 \mu \mathrm{g} / \mathrm{mL}$, respectively. $\mathbf{b}$ Gradient for the analytical RP-HPLC for the quality control of $\left[{ }^{11} \mathrm{C}\right]$ metoclopramide. The mobile phase consist of solvent A: aqueous acetonitrile (90\%), solvent B: water and solvent C: aqueous ammonium phosphate buffer $(50 \mathrm{mM}), \mathrm{pH} 9.3$ adjusted with $\mathrm{NaOH}$ 


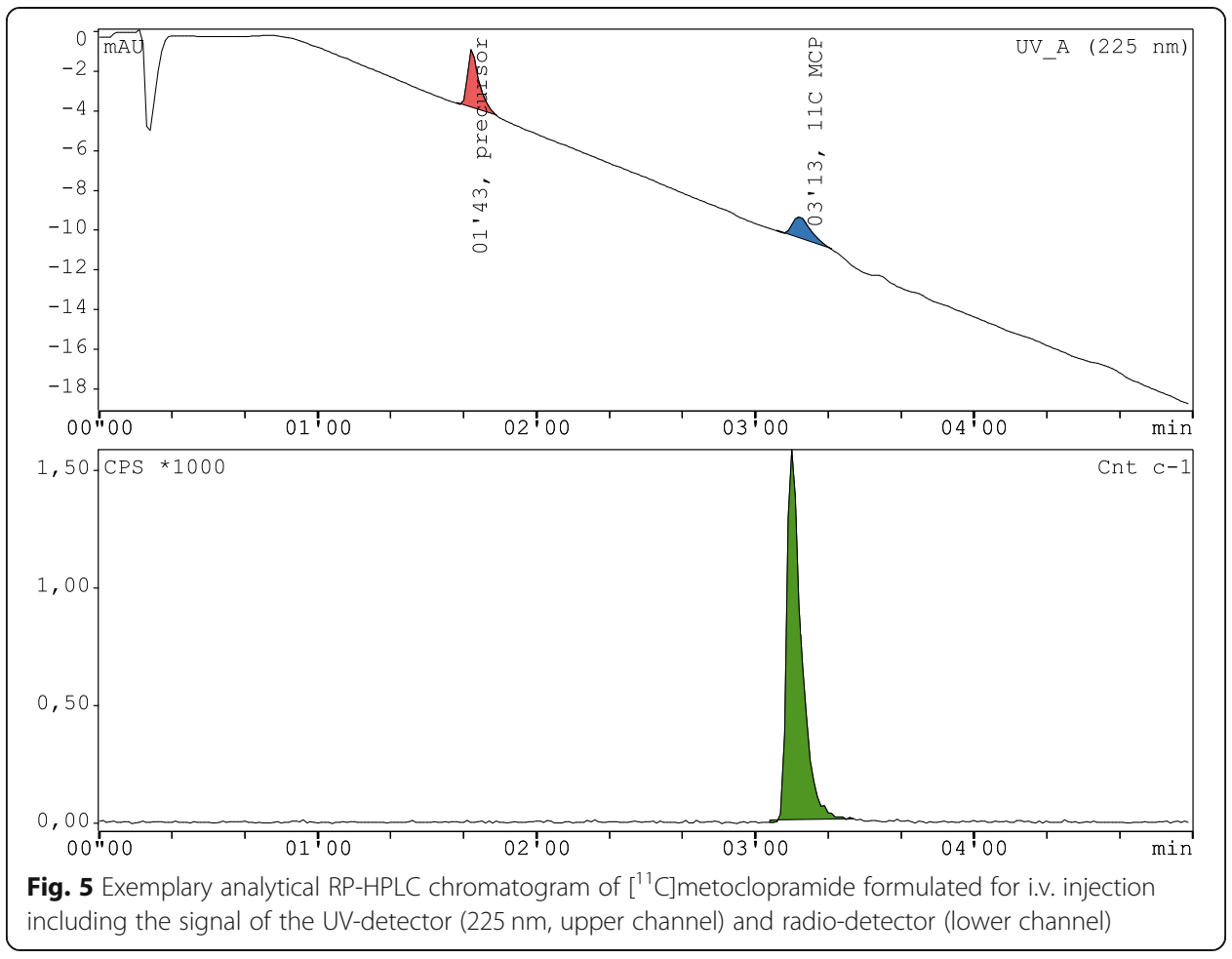

If not indicated otherwise, all values are depicted as mean \pm standard deviation. All results derived from synthesis or quality control were analysed by means of MS Excel ${ }^{\circ}$ 2013. Significance was tested with GraphPad Prims 6 by means of $t$ test analysis.

\section{Results and discussion}

\section{Automated radiosynthesis optimization for human application}

Starting from $116 \pm 17 \mathrm{GBq}$ of $\left[{ }^{11} \mathrm{C}\right] \mathrm{CO}_{2}, 39 \pm 13 \mathrm{GBq}$ of $\left[{ }^{11} \mathrm{C}\right] \mathrm{CH}_{3} \mathrm{OTf}$ was trapped in $400 \mu \mathrm{L}$ butanone within the reactor containing $\mathrm{O}$-desmethyl-metoclopramide and aqueous sodium hydroxide solution after approximately $15 \mathrm{~min}$. In the original radiosynthesis published by F. Caillé and coworkers (Caillé et al. 2018) the $\left[{ }^{11} \mathrm{C}^{1} \mathrm{CH}_{3} \mathrm{OTf}\right.$ was trapped at $-20^{\circ} \mathrm{C}$ in acetone, with subsequent heating to $110^{\circ} \mathrm{C}$. This radiosynthesis had to be adjusted in order to minimize mechanical strain caused by heating acetone over the boiling point and to reduce the effort of maintenance of the synthesis modules, although the chemical turnover in acetone and butanone was comparable during the establishment process (see Table 1). For this reason, the solvent acetone was exchanged by butanone, which additionally enabled the omission of the cooling during the $\left[{ }^{11} \mathrm{C}\right] \mathrm{CH}_{3} \mathrm{OTf}$ trapping step due to its higher boiling point. The trapping efficiency of $\left[{ }^{11} \mathrm{C}\right] \mathrm{CH}_{3} \mathrm{OTf}$ in acetone and butanone was approximately $80 \%$ (non-decay corrected), in accordance to previously published data (Pichler et al. 2018b). Afterwards, the reaction solution was heated to $110^{\circ} \mathrm{C}$ for $2 \mathrm{~min}$, cooled to $\leq 35^{\circ} \mathrm{C}$ and quenched with water. Semi-preparative radio-HPLC (Fig. 3) revealed the presence of the following radioactive peaks: $\left[{ }^{11} \mathrm{C}\right] \mathrm{CH}_{3} \mathrm{I}$ and $\left[{ }^{11} \mathrm{C}\right] \mathrm{CH}_{3} \mathrm{OH}$ (from the reaction of $\left[{ }^{11} \mathrm{C}_{\mathrm{CH}_{3}} \mathrm{OTf}\right.$ and water) at early retention times between 3 and $6 \mathrm{~min}$, followed by a minor unknown side product at $8 \mathrm{~min}$ and the desired product fraction at approximately $12 \mathrm{~min}$. In contrast 
to a previous study (Caillé et al. 2018) the semi-preparative HPLC column was changed from a Waters Symmetry ${ }^{\circ} \mathrm{C} 187.8 \times 300 \mathrm{~mm}, 7 \mu \mathrm{m}$ column to a SUPELCOSIL LC$\mathrm{ABZ}+$ column. After the semi-preparative HPLC purification (Fig. 3), $3.9 \pm 2.0 \mathrm{GBq}$ of product was isolated, which corresponded to a radiochemical yield of $13 \pm 7 \%$ (based on the starting activity of $\left[{ }^{11} \mathrm{C}\right] \mathrm{CO}_{2}$, decay-corrected) or $23 \pm 11 \%$ (based on trapped $\left[{ }^{11} \mathrm{C}\right] \mathrm{CH}_{3} \mathrm{I}$, decay-corrected).

\section{Molar activity and quality control}

The molar activity of the final formulated product was $132 \pm 164 \mathrm{GBq} / \mu \mathrm{mol}$ (range: $5-$ $659 \mathrm{GBq} / \mu \mathrm{mol})$. The molar activity was calculated according to the recently published nomenclature and harmonization guidelines (Coenen et al. 2017). The calibration curve as well as the limits of quantification and detection were determined according to $\mathrm{ICH}$ (International Council for Harmonisation) guidelines (see Fig. 4) (Balaram et al. 2011). If the concentration of metoclopramide was below the limit of detection (LOD), the value was set to the LOD of $0.2 \mu \mathrm{g} / \mathrm{mL}$ for molar activity calculation. Hence, the molar activity was presumably even better than stated in 11 out of 94 production runs, due to hitting the detection limits of the analytical method.

The quality control parameters are listed in Table 2. The parameter radiochemical purity, radionuclidic purity ( $\gamma$ spectrum), half-life, residual solvents as well as the physiological parameters $\mathrm{pH}$ and osmolality were measured before release of the product. Sterility and endotoxin testing were performed after decay of the radioactivity. All parameters were in accordance with the recommendations of the European Pharmacopoeia as applied for other ${ }^{11}$ C-radiotracers (European Directorate for the Quality of Medicines (EDQM) 2016).

\section{Differences and similarities of TRACERlab ${ }^{\mathrm{TM}}$ FX C Pro and TRACERlab ${ }^{\mathrm{TM}}$ FX2 C}

In general, the productions with the TRACERlab ${ }^{\text {tw }}$ FX C Pro afforded significantly lower molar activities $(62 \pm 80 \mathrm{GBq} / \mu \mathrm{mol})$ than the newly installed TRACERlab ${ }^{\mathrm{Tm}}$ FX2 C $(299 \pm 184 \mathrm{GBq} / \mu \mathrm{mol})$. This considerable difference in molar activity can presumably be explained by the long usage of the TRACERlab ${ }^{\text {Tu }}$ FX C Pro leading to carbon deposits. A detailed analysis of potential sources of carbon load in synthesizers has been

Table 2 Quality control parameters for all released batches $(n=81)$ of $\left[{ }^{11} \mathrm{C}\right]$ metoclopramide according to the recommendations of the European Pharmacopoeia for ${ }^{11} \mathrm{C}$-radiotracers

\begin{tabular}{lll}
\hline Quality control parameter & Release criteria & Quality control \\
\hline Radiochemical purity & $>95 \%$ & $99 \pm 1 \%$ \\
Molar activity & no release criteria & $132 \pm 164 \mathrm{GBq} / \mathrm{\mu mol}$ \\
Half-life & $20.3 \pm 2.0 \mathrm{~min}$ & $19.4 \pm 0.8 \mathrm{~min}$ \\
Radionuclidic purity (y-line) & $430-520 \mathrm{keV}$ & $505 \pm 15 \mathrm{keV}$ \\
Residual solvents & $<410 \mathrm{ppm}$ per solvent & $<410 \mathrm{ppm}$ butanone \\
& & $<410 \mathrm{ppm}$ acetonitrile \\
pH & $<10 \%$ ethanol & $<10 \%$ ethanol \\
Osmolality & $4.5-8.5$ & $7.5 \pm 0.2$ \\
Sterility & $200-400$ mosm $/ \mathrm{kg}$ & $316 \pm 37$ mosm $/ \mathrm{kg}$ \\
Endotoxins & pass & pass \\
\hline
\end{tabular}


published by our group recently (Pichler et al. 2018b). The final radioactivity amount of $\left[{ }^{11} \mathrm{C}\right]$ metoclopramide at the end of synthesis was slightly higher for the TRACERlab ${ }^{\text {Tx }}$ FX C Pro than for the TRACERlab ${ }^{\text {tw }}$ FX2 C $(4.2 \pm 1.9 \mathrm{GBq}$ versus $3.4 \pm 2.2 \mathrm{GBq}$, not significant).

The synthetic program of $\left[{ }^{11} \mathrm{C}\right]$ metoclopramide of the TRACERlab ${ }^{\text {tw }}$ FX C Pro had to be adjusted for the TRACERlab ${ }^{\text {Ta }}$ FX2 $\mathrm{C}$ to implement the synthesis of $\left[{ }^{11} \mathrm{C}\right]$ metoclopramide. The main difference between the modules is the changed installation of the silver triflate column (Fig. 2). For the TRACERlab ${ }^{\text {tw }}$ FX C Pro, the silver triflate column has to be inserted before the synthesis in a horizontal position. Here, the main disadvantage lies in the recurrent manual removal and therefore opening of the column which may lead to the introduction of humidity. On the other hand, the exchange of the connecting tubes is easy and fast. For the TRACERlab ${ }^{\mathrm{mi}} \mathrm{FX} 2 \mathrm{C}$, the silver triflate column has a smaller column diameter, and the column is inserted in a vertical position. Here, the silver triflate column can be automatically by-passed and therefore the main disadvantage of the TRACERlab ${ }^{\text {tw }}$ FX C Pro was overcome. However, a disadvantage of the TRACERlab $^{\text {Tx }}$ FX2 $\mathrm{C}$ is the inaccessibility of the connecting tubing between the $\left[{ }^{11} \mathrm{C}_{\mathrm{CH}_{3} \mathrm{I}}\right.$ trap and the silver triflate column. Additionally, the heating and cooling of the silver triflate column has to take place in a mode where the valves are closed and therefore the column may be pressurized.

\section{Analysis of pitfalls of the $\left[{ }^{11} \mathrm{C}\right]$ metoclopramide production}

Overall synthesis success rate was $93 \%$ combined for both modules $(n=94)$. The identified problems are depicted in Fig. 6. The first step with potential failure was the $\left[{ }^{11} \mathrm{C}\right] \mathrm{CH}_{3} \mathrm{I}$ production, for which in some cases no conversion of $\left[{ }^{11} \mathrm{C}\right] \mathrm{CH}_{4}$ into $\left[{ }^{11}\right] \mathrm{CH}_{3} \mathrm{I}$ was observed. A higher failure rate was due to insufficient transformation of $\left[{ }^{11} \mathrm{C}\right] \mathrm{CH}_{3} \mathrm{I}$ into the more reactive intermediate $\left[{ }^{11} \mathrm{C}\right] \mathrm{CH}_{3} \mathrm{OTf}$. In these cases activity was either trapped on the silver triflate column or the activity was successfully transferred to the reactor, but no reaction took place due to insufficient amounts of $\left[{ }^{11} \mathrm{C}\right] \mathrm{CH}_{3} \mathrm{OTf}$. During the semi-preparative HPLC purification step two possible failure scenarios occurred: firstly, there was a poor separation between the side product and the $\left[{ }^{11} \mathrm{C}\right]$ metoclopramide fraction leading to an impure product and subsequently inhibiting product release. Secondly,

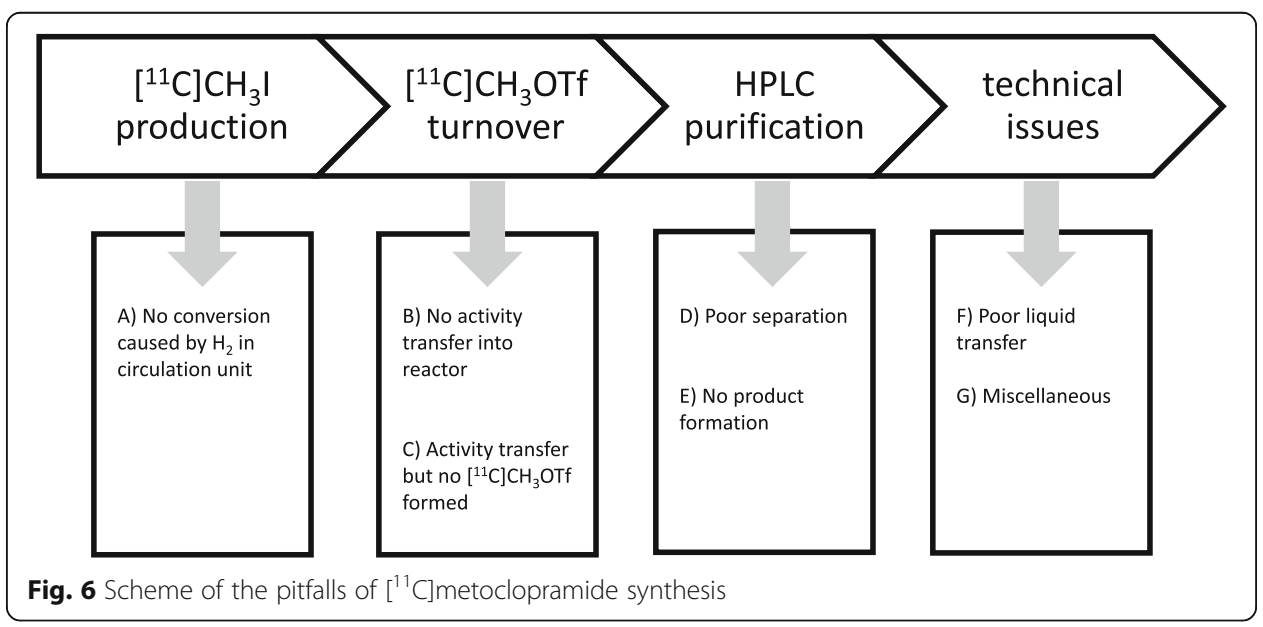


there was no product formation at all, which may be attributed to insufficient conversion of $\left[{ }^{11} \mathrm{C}\right] \mathrm{CH}_{3} \mathrm{I}$ into $\left[{ }^{11} \mathrm{C}\right] \mathrm{CH}_{3} \mathrm{OTf}$ or resulting from traces of decomposed butanone. A test synthesis using $\left[{ }^{11} \mathrm{C}\right] \mathrm{CH}_{3} \mathrm{I}$ as reactive synthon proved the necessity of $\left[{ }^{11} \mathrm{C}\right] \mathrm{CH}_{3} \mathrm{OTf}$ for the preparation of $\left[{ }^{11} \mathrm{C}\right]$ metoclopramide (see Table 1 ). All other synthesis failures were attributable to technical issues like clogging of tubings or valves.

\section{Pitfalls of $\left[{ }^{11} \mathrm{C}_{\mathrm{CH}_{3}}\right.$ l production}

In general, the gas-phase $\left[{ }^{11} \mathrm{C}\right] \mathrm{CH}_{3} \mathrm{I}$ production was very stable and reproducible as described before (Pichler et al. 2018b). However, a potential source of failure in the $\left[{ }^{11} \mathrm{C}\right] \mathrm{CH}_{3} \mathrm{I}$ production could be identified in the course of the evaluation of $\left[{ }^{11} \mathrm{C}\right]$ metoclopramide. In these cases, the characteristic pattern of the re-circulation of $\left[{ }^{11} \mathrm{C}^{1} \mathrm{CH}_{4}\right.$ and trapping of $\left[{ }^{11} \mathrm{C}\right] \mathrm{CH}_{3} \mathrm{I}$ was not observed. Instead, the radioactivity was passing through the $\left[{ }^{11} \mathrm{C}\right] \mathrm{CH}_{3} \mathrm{I}$ trap without any trapping (see Fig. 7). Hence, this failure in $\left[{ }^{11} \mathrm{C}\right] \mathrm{CH}_{3} \mathrm{I}$ production was therefore visible within the first few seconds of the re-circulation process. Once the failure in trapping was noticed, the circulation unit could be flushed with helium and the synthesis could be immediately re-started, as the precursor solution was not affected. In these rare cases, the second run was always successful.

The cause for this failure could be confirmed and the erroneous circulation pattern could be reproduced when the whole circuit unit was flushed with hydrogen $(100 \mathrm{~mL} / \mathrm{min}$ for 2-3 min) instead of helium prior to the $\left[{ }^{11} \mathrm{C}\right] \mathrm{CH}_{3} \mathrm{I}$ production. The introduction of hydrogen into the unit is only explicable, if a valve is leaking or a faulty circuit happens during the conditioning of the $\mathrm{CO}_{2}$ trap. Other (non-commercial) gas-phase $\left[{ }^{11} \mathrm{C}\right] \mathrm{CH}_{3} \mathrm{I}$ production units are not trapping the formed $\left[{ }^{11} \mathrm{C}_{\mathrm{CH}_{4}}\right.$ on a cooled methane trap (personal communication, see also methane trap in Fig. 2) and therefore the produced $\left[{ }^{11} \mathrm{C}\right] \mathrm{CH}_{4}$ is not separated from remaining $\left[{ }^{11} \mathrm{C}\right] \mathrm{CO}_{2}$ and unreacted $\mathrm{H}_{2}$. As the production of $\left[{ }^{11} \mathrm{C}\right] \mathrm{CH}_{3} \mathrm{I}$ in these production units is working properly, we assume that this problem may only occur in presence of high amounts of hydrogen.

\section{Validation of $\left[{ }^{11} \mathrm{C}\right] \mathrm{CH}_{3} \mathrm{OTf}$ production}

Overall, the $\left[{ }^{11} \mathrm{C}\right] \mathrm{CH}_{3} \mathrm{OTf}$ production was more prone to failure than the $\left[{ }^{11} \mathrm{C}\right] \mathrm{CH}_{3} \mathrm{I}$ production and was the main source of synthesis failure. With the set-up of the

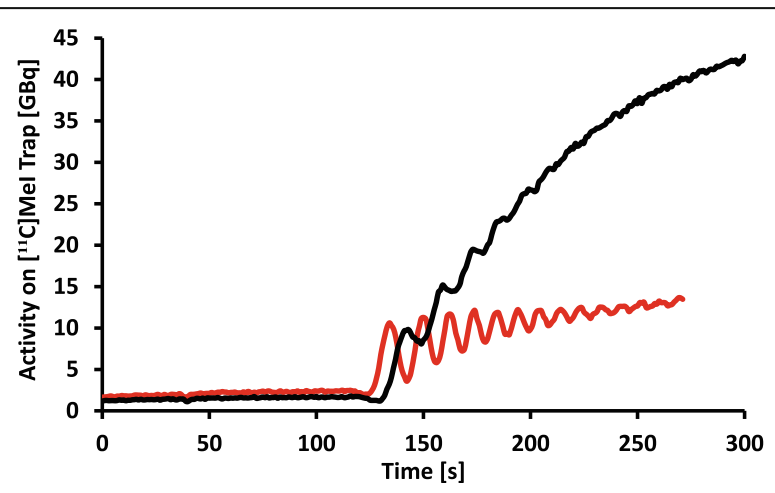

Fig. 7 Progression of the turnover of $\left[{ }^{11} \mathrm{C}\right] \mathrm{CH}_{4}$ to $\left[{ }^{11} \mathrm{C}\right] \mathrm{CH}_{3} l$ and trapping of the activity on the methyl iodide trap, for a successful reaction (black) and failed reaction caused by presence of hydrogen (red) in the circulation unit of the GE TRACERlab ${ }^{\text {TM }}$ FX C Pro synthesizer 
TRACERlab $^{\text {Tw }}$ FX2 C module, two different unwanted scenarios were observed. In the first scenario, the $\left[{ }^{11} \mathrm{C}\right] \mathrm{CH}_{3} \mathrm{I}$ was either almost completely trapped on the silver triflate column or insufficiently transferred from the silver triflate column into the reactor. In the second scenario, a very good transfer of the radioactivity into the reactor was observed, but there was no conversion of $\left[{ }^{11} \mathrm{C}\right] \mathrm{CH}_{3} \mathrm{I}$ into $\left[{ }^{11} \mathrm{C}\right] \mathrm{CH}_{3} \mathrm{OTf}$. The trapping of the $\left[{ }^{11} \mathrm{C}\right] \mathrm{CH}_{3} \mathrm{I}$ on the silver triflate column primarily occurred in our facility, when the silver triflate column was exposed to humidity. However, the main source of failure was the insufficient transformation of $\left[{ }^{11} \mathrm{C}\right] \mathrm{CH}_{3} \mathrm{I}$ into $\left[{ }^{11} \mathrm{C}\right] \mathrm{CH}_{3} \mathrm{OTf}$. Consequently, the silver triflate column must be checked and replaced regularly in order to guarantee a stable process. The exchange of the silver triflate column was performed every 15th20th synthesis for the GE TRACERlab ${ }^{\text {ma }}$ FX C Pro. The successful transformation of $\left[{ }^{11} \mathrm{C}_{\mathrm{CH}_{3} \mathrm{I}}\right.$ into $\left[{ }^{11} \mathrm{C}\right] \mathrm{CH}_{3} \mathrm{OTf}$ was indirectly detected by analytical HPLC analysis of the crude reaction mixture. Although $\left[{ }^{11} \mathrm{C}_{\mathrm{CH}_{3} \mathrm{I}}\right.$ reacts with water of the mobile phase to $\left[{ }^{11} \mathrm{C}\right] \mathrm{CH}_{3} \mathrm{OH}$, a certain amount of non-reacted $\left[{ }^{11} \mathrm{C}_{\mathrm{CH}_{3} \mathrm{I}}\right.$ was detectable (see Fig. 8). $\left[{ }^{11} \mathrm{C}_{\mathrm{CH}_{3} \mathrm{OTf}}\right.$, on the other hand, reacts very quickly with water, so that no

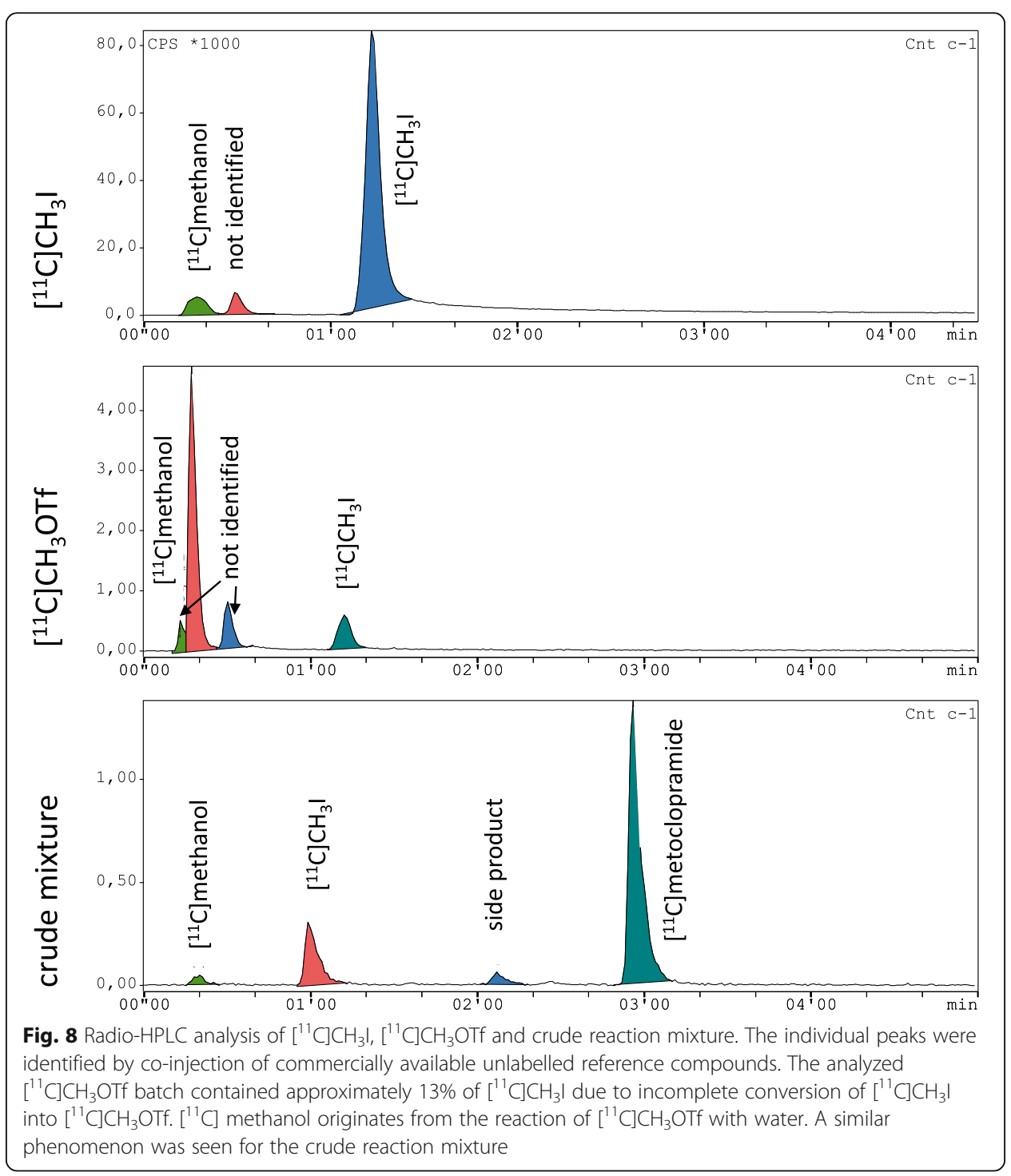


$\left[{ }^{11} \mathrm{C}\right] \mathrm{CH}_{3} \mathrm{OTf}$ peak is detectable but a pronounced $\left[{ }^{11} \mathrm{C}\right] \mathrm{CH}_{3} \mathrm{OH}$ peak. For failure analysis after the synthesis, the injection of the crude reaction mixture into analytical HPLC allows the following conclusions: (i) a detectable $\left[{ }^{11} \mathrm{C}\right] \mathrm{CH}_{3} \mathrm{I}$ peak indicated an insufficient conversion to $\left[{ }^{11} \mathrm{C}\right] \mathrm{CH}_{3} \mathrm{OTf}$, which considerably lowers the radiochemical yield; (ii) if only the $\left[{ }^{11} \mathrm{C}\right] \mathrm{CH}_{3} \mathrm{OH}$ peak was present, the reaction of $\left[{ }^{11} \mathrm{C}^{-} \mathrm{CH}_{3}\right.$ to $\left[{ }^{11} \mathrm{C}_{\mathrm{CH}_{3}} \mathrm{OTf}\right.$ took place, so that other factors, like insufficiently inert atmosphere, among others, were responsible for low product conversion.

\section{Separation efficiency of semi-preparative HPLC and other technical issues}

A poor semi-preparative chromatogram was present, when either there was an insufficient separation of product and side product or there was no product formation at all. For an efficient purification of $\left[{ }^{11} \mathrm{C}\right]$ metoclopramide it was necessary to prepare the mobile phase freshly at least once per week. Otherwise the tailing of the $\left[{ }^{11} \mathrm{C}\right]$ metoclopramide peak enhanced (Fig. 9), as well as the amount of the side peak at around $8 \mathrm{~min}$ appeared to increase. Analysis of the collected semi-preparative HPLC product fraction by analytical HPLC showed that the collected peak consist of both, side product and $\left[{ }^{11} \mathrm{C}\right]$ metoclopramide. Exchange of the HPLC solvent restored the separation and reduced the peak at approximately $8 \mathrm{~min}$.

A reduced or no formation of the product was either due to poor $\left[{ }^{11} \mathrm{C}\right] \mathrm{CH}_{3} \mathrm{OTf}$ formation but also caused by decomposition of the butanone after long time usage (Fig. 9). Acetone is known to undergo aldol reactions when stored on molecular sieves (JoVE Science Education Database 2019). However, GC and ${ }^{1} \mathrm{H}-\mathrm{NMR}$ did not show any aldol reaction product in amounts higher than $0.01 \%$ (GC analysis) or at all $\left({ }^{1} \mathrm{H}-\mathrm{NMR}\right)$ in butanone, which was stored over molecular sieves for more than 6 months. Still, the olfactory differences between the bottle of butanone stored over molecular sieves and a bottle of butanone without molecular sieves suggests that butanone underwent molecular sieve-catalyzed reactions. This small amount of formed aldol product might still be enough to interfere with the radiolabeling via $\left[{ }^{11} \mathrm{C}\right] \mathrm{CH}_{3} \mathrm{OTf}$. Therefore, a regular exchange of butanone at least every 3 months is recommended.

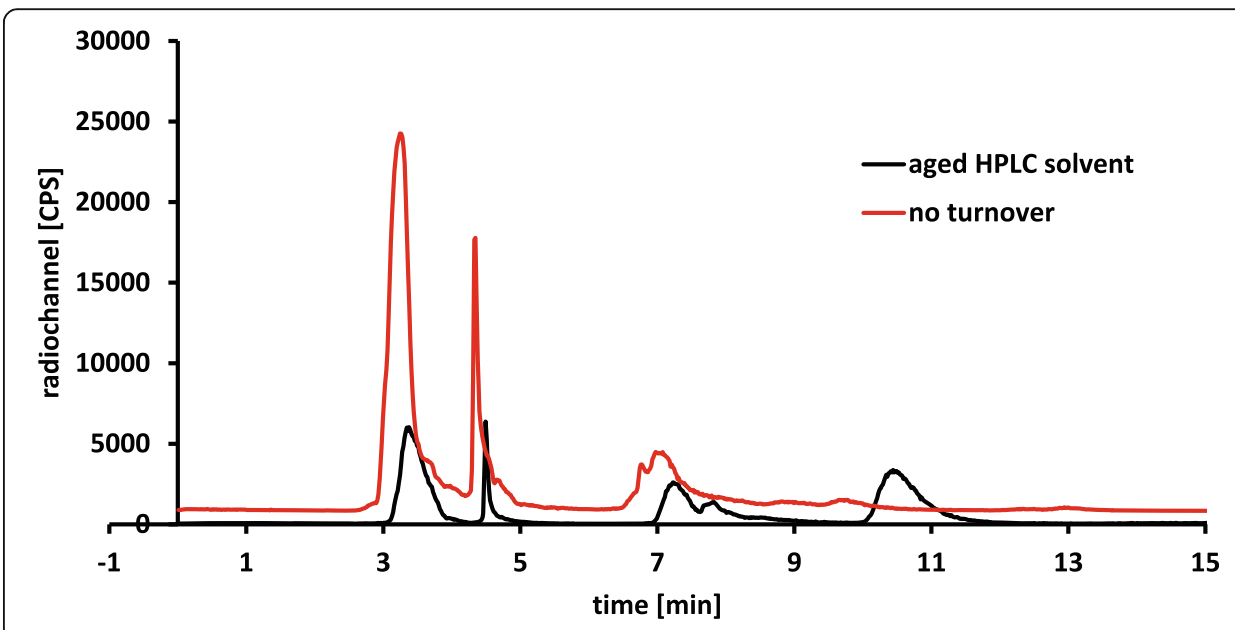

Fig. 9 Insufficient semi-preparative RP-HPLC chromatograms caused by aged HPLC solvent (black) or decomposed butanone (red) 


\section{Conclusion}

$\left[{ }^{11} \mathrm{C}\right]$ Metoclopramide was reliably synthesized on both, a GE TRACERlab ${ }^{\mathrm{mi}}$ FX C Pro and GE TRACERlab ${ }^{\text {tw }}$ FX2 C synthesis module, for more than 100 synthesis in good yields and high molar activities. The quality of the final product was in accordance with the recommendations of the European Pharmacopoeia for other ${ }^{11} \mathrm{C}$-radiotracers. The main technical problems were identified, and individual solutions were developed in order to keep synthesis failures at a minimum.

\section{Abbreviations}

PET: positron emission tomography; P-gp: P-glycoprotein; RP-HPLC: reversed phase-high performance liquid chromatography

\section{Acknowledgements}

The authors thank A. Krcal and T. Zenz for their continuous technical support, F. Caillé (Service Hospitalier Frédéric Joliot, Orsay, France) for advice regarding the set-up of the radiosynthesis and K. Pallitsch for the preparation of silver triflate on carbon. Moreover, the Medical Imaging Cluster at the Medical University of Vienna is acknowledged for supporting this study.

\section{Authors' contributions}

$\mathrm{VP}, \mathrm{MO}$ and $\mathrm{CV}$ conducted the radiosynthesis and quality controls. VP, MO and $\mathrm{KB}$ interpreted the results. VP, MO and $\mathrm{OL}$ wrote the manuscript. $\mathrm{WW}$ and $\mathrm{MH}$ contributed to the design of the experiments and contributed to the writing of the manuscript. All authors read and approved the final manuscript.

\section{Funding}

This work was supported by the Austrian Science Fund (FWF) (grant KLI 694-B30, to O. Langer).

\section{Availability of data and materials}

Please contact corresponding author for data request.

\section{Ethics approval and consent to participate}

This article does not contain any studies with human participants or animals performed by any of the authors.

\section{Consent for publication}

Not applicable.

\section{Competing interests}

All authors declare that they have no financial conflict or competing interests to disclose.

\section{Author details}

'Division of Nuclear Medicine, Department of Biomedical Imaging and Image-guided Therapy, Medical University of Vienna, Vienna, Austria. ${ }^{2}$ Center for Biomarker Research in Medicine, CBmed GmbH, Graz, Austria. ${ }^{3}$ Preclinical Molecular Imaging, AIT Austrian Institute of Technology GmbH, Seibersdorf, Austria. ${ }^{4}$ Department of Clinical Pharmacology, Medical University of Vienna, Vienna, Austria.

Received: 18 October 2019 Accepted: 4 December 2019

Published online: 18 December 2019

\section{References}

Auvity S, Caillé F, Marie S, Wimberley C, Bauer M, Langer O, et al. P-glycoprotein (ABCB1) inhibits the influx and increases the efflux of 11 C-metoclopramide across the blood-brain barrier: a PET study on nonhuman Primates. J Nucl Med. 2018; 59(10):1609-15

Balaram G, Munjal P, Dhagash AP. Validation of analytical procedures: methodology ICH-Q2B. Int J Pharm Innov. 2011;22491031(1):45-50.

Bauer M, Tournier N, Langer O. Imaging P-glycoprotein function at the blood-brain barrier as a determinant of the variability in response to central nervous system drugs. Clin Pharmacol Ther. 2019;105(5):1061-4.

Caillé F, Goutal S, Marie S, Auvity S, Cisternino S, Kuhnast B, et al. Positron emission tomography imaging reveals an importance of Saturable liver uptake transport for the pharmacokinetics of metoclopramide. Contrast Media Mol Imaging. 2018;2018:7310146.

Coenen HH, Gee AD, Adam M, Antoni G, Cutler CS, Fujibayashi Y, et al. Consensus nomenclature rules for radiopharmaceutical chemistry - setting the record straight. Nucl Med Biol. 2017;55:v-xi.

European Directorate for the Quality of Medicines (EDQM). General Monograph 0125 - radiopharmaceutical preparations in european pharmacopoeia. Strasbourg: Council of Europe; 2016.

JoVE Science Education Database. Organic chemistry preparing anhydrous reagents and equipment. Cambridge: JoVE; 2019.

Larsen P, Ulin J, Dahlstrøm K, Jensen M. Synthesis of [11C] iodomethane by iodination of [11C]methane. Appl Radiat Isot. 1997;48(2):153-7.

Nics L, Steiner B, Klebermass E-M, Philippe C, Mitterhauser M, Hacker M, et al. Speed matters to raise molar radioactivity: fast HPLC shortens the quality control of C-11 PET-tracers. Nucl Med Biol. 2018;57:28-33. 
Philippe C, Mairinger S, Pichler V, Stanek J, Nics L, Mitterhauser M, et al. Comparison of fully-automated radiosyntheses of $[11 \mathrm{C}]$ erlotinib for preclinical and clinical use starting from in target produced [11 C]CO2 or [11C]CH4. EJNMMI Radiopharm Chem. 2018;3:1-9.

Pichler V, Vraka C, Berroterán-Infante N, Krcal A, Eidherr H, Traub-Weidinger T, et al. L-[S-methyl-11C] methionine - an example of radiosynthetic optimization. Appl Radiat Isot. 2018a;141(May):107-11.

Pichler V, Zenz T, Philippe C, Vraka C, Berrotéran-Infante N, Pfaff S, et al. Molar activity - the keystone in 11C-radiochemistry: an explorative study using the gas phase method. Nucl Med Biol. 2018b;67:21-6.

Pottier G, Marie S, Goutal S, Auvity S, Peyronneau M-A, Stute S, et al. Imaging the impact of the P-glycoprotein (ABCB1) function on the brain kinetics of metoclopramide. J Nucl Med. 2016;57(2):309-14.

Tournier N, Bauer M, Pichler V, Nics L, Klebermass EM, Bamminger K, et al. Impact of P-glycoprotein function on the brain kinetics of the weak substrate 11C-metoclopramide assessed with PET imaging in humans. J Nucl Med. 2019;60(7):98591.

Vraka C, Pichler V, Pfaff S, Balber T, Hacker M, Mitterhauser M, et al. Technical aspect of the automated synthesis and real-time kinetic evaluation of $\left[{ }^{11}\right.$ C]SNAP-7941. J Vis Exp. 2019;146:1-10.

\section{Publisher's Note}

Springer Nature remains neutral with regard to jurisdictional claims in published maps and institutional affiliations.

Submit your manuscript to a SpringerOpen ${ }^{\circ}$ journal and benefit from:

- Convenient online submission

$\checkmark$ Rigorous peer review

- Open access: articles freely available online

- High visibility within the field

- Retaining the copyright to your article

Submit your next manuscript at $\boldsymbol{\nabla}$ springeropen.com 